\title{
Free Movement of Goods in the Andean Community: How far can Dassonville go?
}

\author{
Yovana Reyes Tagle ${ }^{1}$
}

\section{DRAFT PAPER}

\section{Understanding the principle of free movement of goods in the Andean Community}

\subsection{The conceptual and definitional language in the Cartagena Agreement}

The Cartagena Agreement sets out the principle of free movement of goods, demanding the elimination of "restrictions of all kinds" between Member States. Article 72 thereof states that "the objective of the Tariff Reduction Program is to eliminate the levies and restrictions of all kinds that affect the importation of products originating in the territory of any Member Country."

Additionally, the Cartagena Agreement defines this obligation set out in Article 72 . Article 73 paragraph 2 thereof defines the concept of "restrictions of all kinds” in terms of: “...any administrative, financial, or foreign exchange measure, whereby a Member Country through an unilateral decision, obstructs or hinders imports.” Article 73 of the Cartagena Agreement applies when a restrictive national measure is imposed.

Moreover, the ACJ (Andean Court of Justice) ${ }^{2}$ has used Articles 72 and 73 in conjunction with Article 4 of the Treaty creating the Court of Justice of the Andean Community which enshrined the principle of sincere cooperation. Article 4 thereof states: "Member Countries are under the obligation to take such measures as may be necessary to ensure compliance with the provisions comprising the legal system of the Andean Community. They further agree to refrain from adopting or employing any such measure as may be contrary to those provisions or that may in any way restrict their application." When restrictions on imports have been found to be in breach of the Cartagena Agreement, this provision has also been considered infringed. ${ }^{3}$

Article 72 is to be read together with Article 73 of the Cartagena Agreement. As mentioned above, Article 72 calls for the elimination of "restrictions of all kinds". But in a narrower context, Article 73 defines this concept and refers only to administrative, financial or foreign exchange measures adopted by Member States to obstruct or hinder imports.

\footnotetext{
${ }^{1}$ This paper was funded by a visiting fellowship from the "SECO WTI Academic Cooperation Program". The author thanks Professor Thomas Cottier who took the time to share his views and provide information about this research topic. We thank the staff from the World Trade Institute in Bern for their cooperation and for access to all the facilities to carry out this research.

${ }^{2}$ The ACJ was formally created in 1979 with the adoption of the Treaty creating the Court of Justice of the Andean Community and began its work in 1984. The ACJ's rulings create legally binding decisions for states.

${ }^{3}$ ACJ Ruling 3-AI-96, Ruling 118-AI-2003.
} 
Article 73 of the Cartagena Agreement describes the nature of a restrictive national measure and points out three types of measures. The reference in Article 73 thereof to three forms of restrictions and the omission of any other form merits further consideration. One compelling inference from the definitional language of Article 73 is that restrictions on imports require one of the three types of measures, namely an administrative, financial, or foreign exchange measure. What about the national measures which are outside the scope of these three categories? Article 72 gives the General Secretariat and the ACJ considerable leeway when deciding or interpreting the restrictive nature of a national measure. In spite of the apparent similarities with the principle of free movement of goods in the European Union (EU), however, Article 73 second paragraph narrows the scope of this concept and seems to set some limits to Article 72 of the Cartagena Agreement by including only three types of measures. In this context, what is then the purpose of Article 73 second paragraph? This provision purports to clarify the catch-all notion of restrictions of all kinds. However, the ACJ and the General Secretariat have taken the view that the Cartagena Agreement does not limit the notion of restrictions of all kinds.

The ACJ has suggested what the rationale of a definitional provision in the Cartagena Agreement might be. When the ACJ analyzed the concept of import levies, it reasoned that Article 73 paragraph 1, which contained the definition of levy, does not limit this concept to include only tariffs but rather the provision "generously" broadens the scope of this concept by including any other charge of equivalent effect. ${ }^{4}$ In other words, the ACJ admits that the concept of levies is not limited because the notion of charges of equivalent effect has been introduced by the definition in Article 73. Thus, if this provision would have excluded the notion of any other charge of equivalent effect, would the ACJ have asserted that Article 73 paragraph 1 does impose limits to the concept of levies?

Furthermore, the General Secretariat follows the ACJ approach and emphasizes that under the concept of levies the denomination and the nature of the charge turns out to be irrelevant. ${ }^{5}$ The approach taken in Article 73 paragraph 1 indicates an intention to cover all possible ways in which governments can make imports difficult or impossible by using a hidden tariff. The wording of Article 72 first paragraph suggests that the drafters of the Cartagena Agreement were clearly aware of the notion of measures of equivalent effect (MEQRs). Arguably, the freemovement-of-goods-friendly approach taken by the ACJ in its case law has been underscored by the Sudamtex case that we will discuss below. It seems that these community institutions have realized that trade barriers may take the form of administrative, financial or exchange measures as well as any other form.

Notably, the General Secretariat and the ACJ have followed a different approach when interpreting Article 73 paragraph 1 and Article 73 paragraph 2 of the Cartagena Agreement, namely, the definition of import levies and restriction on imports, respectively. Clearly, the definition of restriction of imports takes into account the nature of a national measure and has not been generously broadened by including measures of equivalent effect. Article 73 does not add any reference to a broad notion such as "other measures", "any other measures" or "any other kind of measures", which has been employed in other international agreements. For example,

\footnotetext{
${ }^{4}$ ACJ Ruling 12-AN-99.

${ }^{5}$ General Secretariat Resolution 967.
} 
Article XI of the General Agreement on Tariffs and Trade (GATT) uses a broad formula including not only the measures mentioned by the provision itself but also a general notion termed "other measures". ${ }^{6}$ The ACJ should utilize its role to provide a reasoned analysis of the underlying purposes of Article 73 second paragraph of the Cartagena Agreement. So far, although the ACJ has defined the concept of administrative, financial and foreign exchange measures, its judgments concerning the purposes of this definitional provision have been limited in scope. Indeed, the ACJ has not answered the question of what the rationale behind legal norms, such as Article 73 second paragraph established by the Cartagena Agreement, is.

\subsection{Exceptions to the free movement of goods}

There are some situations where, subject to certain conditions, Member States are allowed to impose restrictions upon trade. The second paragraph of Article 73 of the Cartagena Agreement sets forth various types of specific exceptions to the principle of free movement of goods in the following terms:

"Not included in this concept are the adoption and enforcement of measures for: a. The protection of public morality; b. The application of laws and regulations related to security; c. The regulation of arms, ammunition, and other implements of war, and under exceptional circumstances, of all other military articles, as long as it does not interfere with what is provided in treaties in force between Member Countries relating to the freedom of transit; $d$. The protection of human, animal, or plant life and health; e. Import and export of metallic gold and silver; $\mathrm{f}$. The protection of national treasures of artistic, historic, or archaeological value; and g. The exportation, use, or consumption of nuclear materials, radioactive products, or any other material that may be used in the development and use of nuclear energy.”

This list of exceptions has some similarities to Article 36 Treaty on the Functioning of the European Union (TFEU). ${ }^{7}$ However, there are two distinctions that can be observed between the two provisions. First, Article 36 TFEU sets forth two specific conditions with which states have to comply. Their national measures must not constitute an arbitrary discrimination or a disguised restriction on trade. These tests have not been included in Article 73 of the Cartagena Agreement. Second, the Cartagena Agreement itself does not allow derogation to the free movement of goods based on the protection of industrial and commercial property.

\footnotetext{
${ }^{6}$ Article XI.1 of the GATT reads as follows: "No prohibitions or restrictions other than duties, taxes or other charges, whether made effective through quotas, import or export licences or other measures, shall be instituted or maintained by any contracting party on the importation of any product of the territory of any other contracting party or on the exportation or sale for export of any product destined for the territory of any other contracting party.”

${ }^{7}$ Article 36 TFEU provides for the list of exceptions to the general rule of Article 34. This provision states that "The provisions of Articles 34 and 35 shall not preclude prohibitions or restrictions on imports, exports or goods in transit justified on grounds of public morality, public policy or public security; the protection of health and life of humans, animals or plants; the protection of national treasures possessing artistic, historic or archaeological value; or the protection of industrial and commercial property. Such prohibitions or restrictions shall not, however, constitute a means of arbitrary discrimination or a disguised restriction on trade between Member States.”
} 


\subsection{Limits to the Member States' freedom to introduce restrictions on trade}

The Cartagena Agreement has included a standstill clause. Article 77 thereof prohibits Member States from introducing restrictions of all kinds on the importation of products which originate in the Andean Community. ${ }^{8}$

The case law of the ACJ regarding Article 77 is worth mentioning. In a preliminary ruling, the ACJ took the view that the legal norms which limit freedom should be narrowly interpreted since they are an exception to the general rule. This hermeneutic principle of interpretation, according to the ACJ, applies to Article 77 since the clear objective of this provision is to set limits to the freedom initially enjoyed by states to impose levies. The ACJ concluded that such limitations must be narrowly interpreted. ${ }^{9}$ Since Article 77 also regulates the prohibition to introduce new restrictions of all kinds, a narrow interpretation should also be applied in this case.

Over the years, the approach towards Article 77 has varied. During the 1990s, the General Secretariat used to invoke Article 77 to emphasize that the restriction on imports considered as such in the case at hand and subject to its Resolution, was also a violation of Article $77 .{ }^{10}$ Thus, Articles 72, 73, 74 and 77 constituted the core legal basis for the Resolutions of the General Secretariat to determine the existence of restrictions on imports. Later on, in some cases, the General Secretariat limited itself to quoting this provision without further observations or analysis of its scope, ${ }^{11}$ and in other cases, it has not even mentioned it. ${ }^{12}$ More recently, however, the General Secretariat seems to have been following a different approach and its Resolutions no longer invoke the violation of Article 77 but rather warn Member States that if they do not remove the restriction on imports subject to its Resolution, a breach of Article 77 may occur. ${ }^{13}$ This warning approach seems to be more consistent with the provisions of the Cartagena Agreement. Indeed, Article 74 thereof only empowers the General Secretariat to determine the existence of a restriction on imports. The violation of Article 77 can take place only after the issuance of its Resolution. This approach reflects a logical order. In the Andean Community, restrictions on trade contrary to the Cartagena Agreement only exist when the General Secretariat so declared them. An infringement of Article 77 presupposes the existence of new restrictions on trade.

\footnotetext{
${ }^{8}$ Article 77 states that "The Member Countries shall refrain from changing the levels of the levies and from introducing any new restrictions on the importation of products which originate in the Subregion, in any way that would create a less favorable situation than that in existence at the time the Agreement comes into effect.” Similarly, the second paragraph of Article 37 TFEU precludes Member States from introducing any new measure "which restricts the scope of the articles dealing with the prohibition of customs duties and quantitative restrictions between Member States", that is to say, Article 34. According to the ECJ interpretation, this provision (former Article 37) does not prohibit every "new measure”. See Case 13/70 Francesco Cinzano \& Cia GmbH v Hauptzollamt Saarbrücken. [1970] E.C.R 1089.

${ }^{9}$ ACJ Ruling 1-IP-90, ACJ Ruling 3-IP-93.

${ }^{10}$ General Secretariat Resolution 184, Resolution 201, Resolution 209.

${ }^{11}$ General Secretariat Resolution 1043.

${ }^{12}$ General Secretariat Resolution. 986.

${ }^{13}$ General Secretariat Resolution 1289.
} 


\section{An overview of restrictions on imports in the Andean Community}

\subsection{Determination of restrictions on trade: an administrative stage}

The General Secretariat ${ }^{14}$ is entitled to qualify whether a state measure constitutes a restriction on imports on a case-by-case basis. Article 74 of the Cartagena Agreement contains a procedural requirement. By virtue of this provision, "the General Secretariat, on its own initiative or at the request of a party, shall determine, when necessary, if a measure adopted unilaterally by a Member Country constitutes a 'levy' or 'restriction'.”

The General Secretariat is obligated to explain the reasons of fact and law based upon which it considers that a national measure is to be regarded as a restriction on imports. To this end, when Member States fail to fulfill Articles 72 and 73 of the Cartagena Agreement, the General Secretariat must issue a Resolution that determines the existence of a restriction on imports before the ACJ can make a judgment. The ACJ may uphold, modify or overturn the decision of the General Secretariat. ${ }^{15}$ The General Secretariat has brought infringement actions against the Member States where its Resolutions determining the existence of restrictions on imports were not fulfilled. Up to now, all the national measures considered restrictions on trade by the General Secretariat have been accepted by the ACJ.

The ACJ has explained the scope of Article 74 and according to its case law, this competence of the General Secretariat is exclusive and in order for such a restriction on imports to exist within the Andean Community, this executive body has to determine its existence in a particular case. ${ }^{16}$ According to the ACJ, Article 74 seeks to control the activity of Member States. ${ }^{17}$ This provision grants the General Secretariat considerable leeway to initiate procedures to assess the nature of national measures that may breach the principle of free movement of goods.

The General Secretariat's position remained the same during the period 1992-2009. We reviewed 47 Resolutions issued in this period by the General Secretariat and its predecessor the former Junta requesting their opinion over allegedly restrictive measures adopted by Member States. Surprisingly, during the period December 2009-July 2012, there were no Resolutions over restrictions on imports adopted by the General Secretariat.

The General Secretariat assesses many cases brought before it with the definition of a restriction on imports developed by the ACJ in its ruling 5-IP-90. The General Secretariat has, on a number of occasions, confirmed that Articles 72 and 73 Cartagena Agreement apply to:

\footnotetext{
14 The structure and functions of the General Secretariat resemble those of the EU Commission.

15 There is a special administrative procedure and deadlines regulated by secondary law as regards the determination of restrictions on imports in the Andean Community. Decision 425 of the Commission of the Andean Community ${ }^{15}$ deals with all the administrative procedures of the General Secretariat. Articles 46 to 55 of this Andean rule provide for the measures to be taken and the procedures to be followed where a Member State or individuals consider that a national measure applied by a Member State constitutes a restriction on intra-community trade.

${ }_{16}$ ACJ Ruling 3-AI-96, Ruling 1-AI-97.

17 ACJ Ruling 14-IP-2008.
} 
- import licenses or permits, ${ }^{18}$ and the conditions for granting such licenses, such as making import authorizations dependent on the satisfaction of domestic demand, ${ }^{19}$

- the lack of a clear and defined procedure to obtain licenses, lack of transparency in the granting procedure, $^{20}$

- $\quad$ the non-transparent and bureaucratic procedures, lack of clear procedures and stipulated deadlines, ${ }^{21}$

- $\quad$ requirements of prior import authorizations, ${ }^{22}$

- cancellation of authorizations, ${ }^{23}$

- $\quad$ non-authorization to unload a product coming from a Member State, ${ }^{24}$

- import quotas, $^{25}$

- import contingents, $^{26}$

- $\quad$ import prohibition or bans, ${ }^{27}$

- $\quad$ the refusal to issue of phytosanitary authorizations or permits, ${ }^{28}$

- $\quad$ the non-processing of import permits, ${ }^{29}$

- price-fixing, $^{30}$

- minimum prices, $^{31}$

- compulsory requirement of registration as an importer and the unsubscription of the importer from the register due to the lack of imports during a certain period, ${ }^{32}$

- $\quad$ the requirement for a deposit for the registration of financing import operations, ${ }^{33}$

- $\quad$ the requirement for evidence of the end use of imports, ${ }^{34}$

- $\quad$ labeling requirements during the fabrication or production process, ${ }^{35}$

- $\quad$ legislation on technical requirements, ${ }^{36}$

- $\quad$ exchange measures, ${ }^{37}$

- $\quad$ the prohibition of marketing of products in the territory of a Member State, ${ }^{38}$

\footnotetext{
${ }^{18}$ General Secretariat Resolution 967, Resolution 724, Resolution 638, Resolution 604, Resolution 371, Resolution 357, Resolution 184, Resolution 357, Resolution 069, Resolution 184.

${ }^{19}$ General Secretariat Resolution 927, Resolution 371.

${ }^{20}$ General Secretariat Resolution 966.

${ }^{21}$ General Secretariat Resolution 407.

${ }^{22}$ General Secretariat Resolution 604, Resolution 209, Resolution (Junta) 454.

${ }^{23}$ General Secretariat Resolution 209.

${ }^{24}$ General Secretariat Resolution 490

${ }^{25}$ General Secretariat Resolution 634, Resolution 258, Resolution 229, Resolution 069.

${ }^{26}$ General Secretariat Resolution 1043, Resolution 967.

${ }^{27}$ General Secretariat Resolution 986, Resolution 897, Resolution 681, Resolution 440, Resolution 201, Resolution 258, Resolution 430, Resolution 397. See also Resolution 398, Resolution (Junta) 388. This criterion was also confirmed in the Resolution 278, Resolution 432. See also Resolution 498. Resolution (Junta) 432.

${ }^{28}$ General Secretariat Resolution 430, Resolution (Junta) 430, Resolution (Junta) 397.

${ }^{29}$ General Secretariat Resolution 278, Resolution 209.

${ }^{30}$ General Secretariat Resolution 710.

${ }^{31}$ General Secretariat Resolution 244.

${ }^{32}$ General Secretariat Resolution 407.

${ }^{33}$ General Secretariat Resolution (Junta) 476.

${ }^{34}$ General Secretariat Resolution 407

${ }^{35}$ General Secretariat Resolution 759.

${ }^{36}$ General Secretariat Resolution 1289.

${ }^{37}$ General Secretariat Resolution 715.

${ }^{38}$ General Secretariat Resolution 229.
} 
- administrative requirements such as a requirement of a consular legalization to phytosanitary inspection certificates issued by the exporting country's competent authority for the importation of foodstuff, ${ }^{39}$

- $\quad$ the limitation of the import operation to a period of three months, ${ }^{40}$

- conditioning imports upon the previous utilization of national production. ${ }^{41}$

\subsubsection{A market access approach developed by the General Secretariat}

Articles 72 and 73 of the Cartagena Agreement cover not only measures that merely make imports difficult but also measures that prevent access to the market. Thus, any measure, although formally applicable to all traders without distinction, falls within the scope of Articles 72 and 73 of the Cartagena Agreement if it places a greater burden on the importer, thereby obstructing or impeding access to the market for a product originated in a Member State. The General Secretariat has emphasized the idea of market access when determining the existence of restrictions on imports. In its Resolution 724, the General Secretariat cited the writings of the ACJ (Ruling 72-AI-2000, Ruling 3-AI-96 and Ruling 5 IP-90) and came to the conclusion that the application of prior import licenses to refined oil (soy oil and sunflower oil) by Colombia is aimed at restricting access to the market, limiting the importation of such products. This community institution brought these measures within the concept of restriction provided for in Article 73 of the Cartagena Agreement. ${ }^{42}$

This concern for market access in the territory of Andean Member States matches the ECJ case law. The ECJ has held that "national legislation under which bakers, butchers and grocers can make sales on rounds in a given administrative district, such as an Austrian Verwaltungsbezirk, only if they also trade from a permanent establishment in that administrative district or an adjacent municipality where they offer for sale the same goods as they do on rounds”, ${ }^{43}$ "impedes access to the market of the Member State of importation for products from other Member States more than it impedes access for domestic products." ${ }^{44}$ Likewise, in Commision v. Italy, the ECJ made it clear that the concept of MEQRs encompasses "Any other measure which hinders access of products originating in other Member States to the market of a Member State." 45 Thus, according to the ECJ case law, Article 34 TFEU prohibits distinctly applicable measures, indistinctly applicable measures and rules that hinder market access. ${ }^{46}$ In Commission v. Italy, ${ }^{47}$ the ECJ reaffirmed its case law concerning Article 34 TFEU and held that this provision "reflects the obligation to respect the principles of non-discrimination and of mutual recognition of products lawfully manufactured and marketed in other Member States, as well as the principle of ensuring free access of Community products to national markets...”.

\footnotetext{
${ }^{39}$ General Secretariat Resolution 958.

${ }^{40}$ General Secretariat Resolution 357.

${ }^{41}$ General Secretariat Resolution 308.

${ }^{42}$ General Secretariat Resolution 724.

${ }^{43}$ Case 254/98. Judgment of the Court (First Chamber) 13 January 2000, I-167.

${ }^{44}$ Case 254/98. Judgment of the Court (First Chamber) 13 January 2000, I-171.

${ }^{45}$ Case C-110/05 Commission v. Italy. 2009 I-00519. para. 35 and 37.

${ }^{46}$ Barnard, Catherine. The substantive law of the EU: The four freedoms. Oxford University Press: New York, 2010. p. 80.

${ }^{47}$ Case C-110/05 Commission v. Italy. 2009 I-00519. para. 34.
} 
In brief, the following approaches can be distinguished in the Resolutions of the General Secretariat. First, discriminatory and non-discriminatory measures which restrict imports in any manner, by making them difficult, impossible or more costly, are prohibited. Second, a measure that affects market access to a Member State's territory may constitute a restriction on import contrary to the principle of free movement of goods. These approaches fully echoed the ECJ jurisprudence.

\subsection{Free movement of goods in the case law of the Andean Court of Justice}

\subsubsection{The concept of restrictions of all kinds}

The ACJ understands that "restrictions of all kinds" presupposes a general notion, including measure that diminish previous existing rights, of any form or manner, which creates a situation less favorable than that existing before the restriction is applied. The ACJ concludes that a measure of any kind that alters a situation to the detriment of inter-community trade, by limiting or modifying it, constitutes a violation of the Tariff Reduction Program. ${ }^{48}$ It is settled case law that the Tariff Reduction Program constitutes one of the basic pillars in the development of the Andean integration process. ${ }^{49}$ The ACJ has affirmed in its case law that that this Program is one of the mechanisms that the Member States must use to achieve the objectives of the Cartagena Agreement. ${ }^{50}$ The ACJ has reiterated that the Tariff Reduction Program is one of the most important and fundamental mechanisms set forth in the Cartagena Agreement to achieve the objectives of the integration process and, in particular, to attain the gradual formation of the common market. ${ }^{51}$ This Program imposes some limits to the regulatory power of the Member States. In this context, the form, the intention and the purpose of the restriction turns out to be irrelevant in the determination of a restriction on trade. In light of the ACJ case law, a restriction on imports could derive from a legal rule of general application or from a decision for specific addressees, an omission, and any positive or negative attitude. ${ }^{52}$ This ACJ approach resembles that of the ECJ. One of the features of Dassonville is that it refers to the effect rather than the purpose. Indeed, in order to fall within the scope of Article 34 TFEU, the form of an MEQR has not been relevant to the ECJ either, but rather the effect of the measure. ${ }^{53}$

Since the early 1990s, the ACJ has made it clear that a restriction that produces the effect of affecting trade is what the Cartagena Agreement seeks to avoid. ${ }^{54}$ The ACJ has followed an object-effect approach when assessing an allegedly national restrictive measure. It confirmed in

\footnotetext{
${ }^{48}$ ACJ Ruling 5-IP-90. Article 3 of the Cartagena Agreement lists the measures and programs that the Andean Community should develop in order to achieve its objectives. Article $3 \mathrm{~d}$ ) of the Cartagena Agreement envisages the Tariff Reduction Program as one of these programs. This Tariff Reduction Program has the objective of eliminating barriers to trade. According to Article 76 of the Cartagena Agreement this Program shall be automatic and irrevocable.

${ }^{49}$ Ruling 3-AI-98, Ruling 3-AI-96, Ruling 2-AI-97.

${ }^{50}$ ACJ Ruling 1-IP-90, Ruling 3-IP-93, Ruling 1-AI-97.

${ }^{51}$ ACJ Ruling 3-AI-96.

${ }^{52}$ ACJ Ruling 2-AN-98.

${ }^{53}$ Chalmers, Damian, Davies, Gareth, and Monti, Giorgio. European Union Law: Cases and Materials. Cambridge: Cambridge University Press. Second edition. 2010. p. 752.

${ }^{54}$ ACJ Ruling 5-IP-90.
} 
its case law that legal, regulatory or administrative provisions that have the object and effect of making imports impossible are within the scope of "restrictions of all kinds". A restrictive measure is defined as any act issued by a public authority with limiting effects on imports. Such effect may consist in making imports impossible, difficult or more onerous than domestic production. ${ }^{55}$ The ACJ understands the concept of state measure in broad terms and requires that such a restriction on imports be adopted by a body in the exercise of public functions which includes executive, legislative or administrative, control or judicial authorities. ${ }^{56}$ The ACJ has continued to issue rulings that have reproduced this reasoning. ${ }^{57}$

Two similarities to the ECJ case law can be noted. First, with respect to the source of trade barriers, it follows from Article 73 of the Cartagena Agreement that in order to bring Articles 72 and 73 into play, a state measure is required. Article 73 is more precise and states that a restriction on imports constitutes a unilateral decision adopted by a Member Country. Likewise, in the EU, Article 34 TFEU is addressed to the Member States. A state measure is required, which includes not only national laws and regulations but also other acts such as the acts of regional or local authorities. Gromley notes that "the concept of what constitutes a state measure is extremely wide and extends to include acts of bodies which are not part of the state machinery when those acts may be attributed to the state." 58 Second, the ECJ has concluded that "measures adopted by a Member State the object or effect of which is to treat products coming from other Member States less favourably are to be regarded as measures having equivalent effect to quantitative restrictions on imports...”. ${ }^{59}$ Generally speaking, this definition matches the ACJ case law.

Moreover, the ACJ provided a definition of the concepts of administrative, financial or exchange measures in its Ruling 5-IP-90 and reiterated them in subsequent rulings. ${ }^{60}$ According to the ACJ, administrative measures can include minimum or maximum price-fixing less favorable to imported products, and direct limits on imports. Foreign exchange measures are measures that hinder the free, open and full functioning of the currency market. This classification embraces measures that affect the amount of currency availability for imports payments, quantitative restrictions on currency exchange, prior exchange licenses or authorizations, currency quotas depending on the imports at hand, and requirements for advance purchase of currency, among others. Likewise, the ACJ has pointed out that those financial controls that include the regulations on loans for import payments and the cost of foreign funding and its availability are another type of restrictions in light of Article 73 of the Cartagena Agreement. ${ }^{61}$

The definition of restrictive measure given by the ACJ very closely resembles that of "measures" provided for in the former European Commission Directive 70/50 of 1969 and even includes

\footnotetext{
55 ACJ Ruling 5-IP-90, Ruling 3-AI-96, Ruling 2-AN-98, Ruling 11-IP-2008.

${ }^{56}$ ACJ Ruling 2-AN-98.

${ }^{57}$ ACJ Ruling 14-IP-2008, Ruling 117-AI-2003.

${ }^{58}$ Gormley, Laurence W. EU Law of Free Movement of Goods and Customs Union. United States: Oxford University Press, 2009. p. 396-397.

${ }^{59}$ Case C-110/05 Commission v. Italy. 2009 I-00519. para. 37.

${ }^{60}$ ACJ Ruling 2-AN-98, Ruling 117-AI-2003.

${ }^{61}$ ACJ Ruling 5-IP-90.
} 
some of the measures listed by the Directive in Article 2.3. ${ }^{62}$ This Directive was a provision applied to the transitional period in European integration and is no longer applicable; nevertheless, it has influenced the case law of the Andean institutions. Although since 2000 the General Secretariat has not expressly cited Directive 70/50 in its Resolutions, as it had done before, ${ }^{63}$ as will be discussed below, this Directive, together with the ECJ case law shaped the Andean understanding of the principle of free movement of goods.

\subsubsection{Assessment of a national measure}

In the ACJ jurisprudence on the free movement of goods, it can be seen that the order of assessment employed to determine whether a national measure adopted by a Member State constitutes a restriction on trade duplicates the manner in which the ECJ has assessed national measures in the EU. One of the approaches followed by the ECJ when assessing national rules in the light of Article 34 TFEU is "it has (1) simply noted that the national measure 'impedes', 'hinders', or creates an 'obstacle' to inter-state trade, making little or no reference to the question of discrimination, and then (2) considered whether a mandatory requirement or and Article 36 derogation applies." ${ }^{64}$ Gormley observes that the classical Dassonville approach consists of two steps: the analysis of whether "there is clearly a barrier to trade between Member States, and then proceeding to deal with the alleged justification." ${ }^{65}$ The methodology followed by the ECJ has also been employed by the Andean institutions. Similarly to the analysis undertaken by the ECJ, the ACJ has followed a two-tier approach when addressing any alleged infringement of Articles 72 and 73 of the Cartagena Agreement. First, the ACJ reviews whether a national measure obstructs or hinders imports. Second, it assesses whether such a measure can be justified under the exceptions laid down in Article 73 second paragraph. This approach is also evident in all the Resolutions of the General Secretariat.

It is noteworthy that when the ACJ embarks upon this kind of analysis it has sometimes showed some inconsistency. In some cases, the ACJ held that not all restrictions to free trade are illegal per se in the framework of the Cartagena Agreement. The ACJ went on to add that there are exceptions provided for in the current Article 73 that justified the limitation or prohibition on imports. ${ }^{66}$ Likewise, the ACJ has declared that intra community trade should be free of tariff and non-tariff barriers, save for the restrictions allowed as exceptions. ${ }^{67}$ In other cases, the court states that the national measure at hand is not a restriction on trade because it is justified by the treaty based-exceptions. For instance, the ACJ has held that Article 73 of the Cartagena Agreement lists the exceptions to the measures which Member States can unilaterally adopt and

\footnotetext{
${ }^{62}$ Directive 70/50 stated that "for the purpose of Article [34 TFEU] et seq. `measures' means laws, regulations, administrative provisions, administrative practices, and all instruments issuing from a public authority, including recommendations". In addition, Article 2.1 of the Directive 70/50 stated that such measures should "hinder imports which could otherwise take place, including measures which make importation more difficult or costly than the disposal of domestic production." Article 2.3 of Directive 70/50 referred to minimum or maximum prices as forms of restrictions.

${ }^{63}$ General Secretariat Resolution 047.

${ }^{64}$ Barnard, Catherine. The substantive law of the EU: The four freedoms. Oxford University Press: New York, 2010. p.103.

${ }^{65}$ Gormley, Laurence W. Free Movement of Goods and Their Use -What Is the Use of It? In: Fordham International Law Journal Vol. 33, Issue 6, 2011.p. 1597.

${ }^{66}$ ACJ Ruling 5-IP-90.

${ }^{67}$ ACJ Ruling 2-AI-96.
} 
which do not amount to restrictions. In the same Ruling, the ACJ noted that the former Junta relates its Resolution 397 to the spirit, scope and objective of the national restrictions or prohibitions authorized by Article 73. ${ }^{68}$ In the same vein, the ACJ affirmed that a measure of any kind which diminishes, limits or modifies a situation to the detriment of intra community trade, save for the allowed exceptions, constitutes a restriction on trade. ${ }^{69}$ The ACJ has failed to note that in the latter cases, a justified national measure is still a restriction on trade and the difference lies in the justification for accepting its application. If there is no restriction on trade, why does the national measure need to be justified? Reliance on the exceptions presupposes the existence of a restriction on trade. But how did the ACJ come up with this reasoning? Two explanations are possible. First, not surprisingly, the same mistake is found in the case law of the ECJ. Gormley quotes the ECJ judgment in Commission v. Italy (Case C-110/05 of 2009) and found the same line of assessment used by the ECJ. He correctly adds "If a measure is justified, it does not cease to be a measure having equivalent effect; it is merely a measure which is accepted, having been reviewed for necessity and proportionality, because of the interest or value pursued. The trade-restricting effects do not disappear! This logical mistake is all too frequently made and really ought to stop." 70 Taking into account that the ACJ has long looked to the decisions of the ECJ for guidance, it seems that one of the reasons why the ACJ has made this kind of assessment may be found in the ECJ case law. This in turn reveals the risks of mechanically applying the structural reasoning of the ECJ and reproducing even its "logical mistake”, as Gormley put it. ${ }^{71}$

Second, it is submitted that the wording of Article 73 second paragraph of the Cartagena Agreement has been constructed in such a way as to lead to this error. As noted above, this provision defines the concept of restrictions of all kinds and lists the exceptions to the free movement of goods. However, when referring to those exceptions it states: "Not included in this concept [restrictions of all kinds] are the adoption and enforcement of measures for", the protection of public morality and the application of laws and regulations related to security, among others. In this context, the ACJ has noted that the prohibition on introducing limitations to the free movement of goods is not absolute. The ACJ understands that the text of the Cartagena Agreement suggests that the adoption and fulfilment of measures aimed at protecting the public interest objectives listed in Article 73 do not have a restrictive nature. ${ }^{72}$ Indeed, by excluding measures adopted for protecting legitimate national objectives from the concept of restrictions of all kinds, Article 73 suggests that they should not be regarded as restrictions on trade and overlooks the fact that the restrictions on trade continue to exist even though they are justified. Neither the ACJ nor the General Secretariat has expressly remarked on this aspect of the Cartagena Agreement in its case law.

\footnotetext{
${ }^{68}$ ACJ Ruling 3-AI-96.

${ }^{69}$ ACJ Ruling 11-IP-2008.

${ }^{70}$ Gormley, Laurence W. Free Movement of Goods and Their Use -What Is the Use of It? In: Fordham International Law Journal Vol. 33, Issue 6, 2011.p. 1614.

${ }^{71}$ Gormley. Op.cit.p. 1614.

${ }^{72}$ ACJ Ruling 136-AI-2004.
} 


\section{The application of Dassonville in the Andean case law: restrictions of all kinds and measures of equivalent effect}

\subsection{Sudamtex case}

We focus on two representative cases that illustrate the utilization of the Dassonville formula to better understand the extent to which this formula has been applied. In the EU, if national measures are likely to hinder imports between Member States, they may be in breach of Article 34 TFEU. It should be noted that Article 34 TFEU provides that "Quantitative restrictions on imports and all measures having equivalent effect shall be prohibited between Member States.” Consequently, unlike Article 34 TFEU, Articles 72 and 73 of the Cartagena Agreement contain no reference either to the notion of quantitative restrictions or to the notion of MEQRs. Clearly, quantitative restrictions are among the most common restrictions to trade and on this basis measures such as quotas, prior licenses, and import registers have been regarded in the Andean Community as quantitative restrictions, which are prohibited. ${ }^{73}$

The ECJ has ruled that "all trading rules enacted by Member States which are capable of hindering, directly or indirectly, actually or potentially, intra-community trade are to be considered as measures having an effect equivalent to quantitative restrictions." ${ }^{74}$ This Dassonville formula has been of considerable importance in the EU to the extent that some scholars comment that "it has almost acquired the status of an additional Article in the [TFEU]". ${ }^{75}$ The wording of this judgment has been constantly repeated in several ECJ judgments. ${ }^{76}$ The review of the case law in the Andean Community reveals that all the variables in this formula have been acknowledged in the Andean Community. In the Sudamtex case, the General Secretariat and the ACJ sought to make clear the scope of the free movement of goods. They showed their willingness to set out the scope of the free movement of goods in the same terms as the ECJ did in Dassonville.

The facts of the Sudamtex case are as follows. After reviewing several declarations of imports, the Colombian customs authorities considered that Sudamtex de Colombia had imported goods without the due declaration, omitting to declare one or more elements concerning descriptions of goods, which were compulsory for importers. The national competent authorities required Sudamtex de Colombia to put at the disposal of that office, within a maximum period of 15 days, the goods related to the declarations of imports. The national authorities opened a formal investigation against Sudamtex to assess the fulfillment of customs provisions, and proposed the application of a fine of 200 per cent of the value of goods. In this context, the question of the

\footnotetext{
${ }^{73}$ General Secretariat Resolution 229.

${ }^{74}$ Case 8/74 Procureur du Roi v Benoît and Gustave Dassonville [1974] E.C.R 00837.

${ }^{75}$ Cairns, Walter. Introduction to the European Union Law. London: Gavendish Publising Limited, 1997. p. 143.

${ }^{76}$ See e.g. Joined cases 266 and 267/87. The Queen v Royal Pharmaceutical Society of Great Britain, ex parte Association of Pharmaceutical Importers and others. [1989] E.C.R 1295; Case 82/77 Ministère public du Kingdom of the Netherlands v Jacobus Philippus van Tiggele [1978] E.C.R 00025; Case 72/83 Campus Oil Limited and others v. Minister for Industry and Energy and others [1984] E.C.R. 02727; Case 448/98 Criminal proceedings against Jean-Pierre Guimont [2000] E.C.R. I-10663; Case 254/98 Schutzverband gegen unlauteren Wettbewerb v TKHeimdienst Sass GmbH [2000] E.C.R. I-0015.
} 
breach of the Cartagena Agreement, in particular the principle of free movement of goods, was brought before the General Secretariat.

The Sudamtex case gave rise to two Resolutions of the General Secretariat and one ACJ judgment. The nullity action was brought by Colombia against the General Secretariat. Colombia argued that the national authorities did not make imports difficult or impossible and the possibility to continue with the importation of goods was not affected. Colombia concluded that the investigation of the customs authorities did not produce effects in the legal order. From its point of view, there was no prohibition on the importation or sale of a product. However, the General Secretariat and the ACJ took the view that its investigation and the proposed fine achieved the same trade-hindering effect.

The ACJ took into consideration that although the fine was only a proposal, there was an order issued by the Colombian authorities requiring the importer to put the goods at their disposal. After assessing the performance of the customs administration, the ACJ concluded that the measure adopted produced legal effects likely to injure the principle of free movement of goods.

Colombia argued that provisional acts aimed at preparing a decision cannot be challenged. However, the ACJ expressed the view that that in order to fall within the scope of Article 73 of the Cartagena Agreement, it is irrelevant whether a national measure constitutes a definitive practice, or a final or pending administrative act. In its opinion, there is no need to exhaust internal administrative or judicial resources provided in the internal legal order of the Member States. The reasoning of the ACJ was that that it is enough if the measure has the direct or indirect effect of making imports difficult. The ACJ concluded that the definitive or preparatory nature of an internal act is not decisive in qualifying a measure as a restriction on imports but rather the restrictive effect that it may eventually produce on current or future imports. The ACJ stressed that community law seeks to eliminate all kind of obstacles that directly or indirectly make imports difficult or impossible. The idea behind the ACJ's assertions is the Dassonville formula that the General Secretariat clearly endorsed in Resolutions 019 and 047 issued on the occasion of this case. ${ }^{77}$

In the Sudamtex case, the General Secretariat and the ACJ took the view that it makes no difference at what point the import restriction is made, whether at the time of crossing the border or subsequently. The General Secretariat reiterated this opinion in its Resolution 453 where, quoting its Resolution 019 issued in the Sudamtex case, it took the view that one of the measures that can cause difficulties in trade between Member States is the excessive and disproportional formalities and procedures that must be completed when the goods cross the border or after crossing the border. ${ }^{78}$ Relying on precedents from the ECJ (Case 159/78), the ACJ asserts that one of the internal measures that can create difficulties in trade between Member States is the formalities and excessive and disproportional procedures to be fulfilled when goods coming from one Member State cross the border of another Member State, as well as after crossing the border. The ACJ states that the collection of statistical information at the internal border or the collection of taxes does not justify systematic controls and excessive formalities applied to imports. ${ }^{79}$

\footnotetext{
${ }^{77}$ ACJ Ruling 2-AN-98.

${ }^{78}$ General Secretariat Resolution 453.

${ }^{79}$ ACJ Ruling 2-AN-98.
} 
This case sheds light on how the scope of Article 73 of the Cartagena Agreement was extended to include potential acts. The Dassonville formula has served to clarify the scope of the competence of the General Secretariat provided for in Article 74 of the Cartagena Agreement. Faced with the Colombian argument that affirmed that the General Secretariat lacked the competence to review and decide on pending acts and that Article 74 cannot be extended to include potential acts, the General Secretariat based its argument on the ECJ's Dassonville doctrine, and a teleological interpretation of Article 74 and held that it was within its competence to review national measures that may actually or potentially affect trade.

It should be recalled here that the ACJ has repeatedly resorted to the origins and goals of the Andean integration process to emphasize the need to eliminate all obstacles to trade, whatever their nature or form, in order to achieve a common market. In a preliminary ruling in 1990, the ACJ left the national judge to consider in his analysis the direct relationship between the restrictive national measure and its effect on reducing imports, or the imminent threat to reduce them, in order to determine whether or not the restriction was contrary to the Cartagena Agreement. ${ }^{80}$ The text of the Cartagena Agreement does not refer to the threat to affect imports and the ACJ has not explicitly stated in that case that an imminent threat constitutes a violation of Andean rules in the context of the free movement of goods. However, by introducing the notion of imminent threat in the determination of a restriction on trade, the ACJ indirectly suggested that such a threat might be an infringement of the principle of free movement of goods.

In the Sudamtex case, clearly, the trade-restrictive effects of the Colombian measures were the main concern of the General Secretariat and the ACJ. In their view, the mere fact of proposing a disproportional fine, together with an unreasonable investigation, when all the import documents have been submitted and all the charges levied have been paid, amounts to a restriction on trade. The General Secretariat has repeated this argument in its Resolution 453 where it held that disproportional and unnecessary acts of authorities constitute a restriction on imports. In this case, Colombia claimed that the seizure of a shipment of 25 tons of potatoes by Venezuela constituted a restriction on imports. However, the General Secretariat noted that Colombia did not prove that the measure was excessive and disproportional, and therefore in the General Secretariat' opinion, such a measure did not amount to a restriction on imports.

To sum up, the General Secretariat referred to the Dassonville case as a decisive premise for the decision on a given case. In the context of Article 73 of the Cartagena Agreement, the difficult question remains to what extent this formula should be applied and where the Dassonville formula stops in the Andean Community. One subsequent case showed that the General Secretariat reaffirmed the application of the Dassonville formula.

\section{2. $\quad$ ABBA case}

In its Resolution 449, the General Secretariat ruled that the opening of an investigation procedure by Peru into the smuggling of blankets originating from Ecuador, without justification, technical

\footnotetext{
${ }^{80}$ ACJ Ruling 5-IP-90.
} 
support or proof constituted a restriction on trade in so far as such an investigation had the effect of preventing the importer from putting the goods on the market. The General Secretariat took the view that the commercial discredit or threat of penal procedures would deter further imports, thus making imports more difficult or onerous. The General Secretariat made it clear that police or fiscal control imposed in the import-receiving country do not constitute a restriction on trade when the end pursued is valid. However, it reaffirmed its findings in Resolution 047 concerning the Sudamtex case, repeated the Dassonville formula, and asserted its competence to rule on measures that may have restrictive effects, such as the case at hand.

Again, this case illustrates the General Secretariat's approach to assessing the limiting and prohibiting effects of national measures on imports when determining the existence of restrictions in light of Articles 72 and 73 of the Cartagena Agreement. The General Secretariat reaffirmed, quoting its Resolution 047, that this has been the practice of the WTO and the EU Commission as well as some other multilateral and regional organizations. In this case, the General Secretariat quoted the European doctrine concerning the interpretation of Article 34 TFEU to emphasize that the understanding concerning the scope of this provision is that it includes measures with potential restrictive effects. ${ }^{81}$ Accordingly, the General Secretariat has reserved itself the power to review any national measure that may affect trade, even a potential act.

\subsection{Beyond the Dassonville formula}

Another aspect that should be mentioned concerning the application of the Dassonville formula is that the General Secretariat erroneously went beyond the text and objective of this formula in the Sudamtex case. The General Secretariat in its Resolution 019, after determining that the measures adopted by Colombia constituted restrictions on imports, imposed two obligations on the Colombian government. According to the General Secretariat, Colombia must not a) require the inclusion of minimum descriptions of goods which are not necessary for the right classification and the determination of the value of the goods at customs, b) impose fines that are not related to the nature of the infringement upon goods coming from Member States.

Colombia requested the General Secretariat to reconsider its Resolution 019 and argued that this community institution had no right to instruct a state how to apply its domestic law or to prohibit a state from specific behaviors. The General Secretariat issued Resolution 047 confirming its previous decision. In an attempt to justify its instructions to Colombia, in an erratic manner, the General Secretariat in Resolution 047 quoted again the Dassonville formula and argued that in this case, the ECJ held that the elimination of barriers to intra-Community trade include quantitative restrictions together with the prohibition of MEQRs. Thus the General Secretariat argued that it was not indicating how the Member States must fulfill their norms but rather requiring them to comply with community law. To this end, according to this community institution, it is necessary to indicate the acts that must be done. The ACJ rightly overruled this decision of the General Secretariat and correctly held that in the interpretation made by the ECJ in the Dassonville case, the European court did not refer expressly to complementary measures

\footnotetext{
${ }^{81}$ General Secretariat Resolution 449.
} 
that one community institution was entitled to adopt as a consequence of a decision that qualified an internal measure as a restriction on trade.

Indeed, Article 74 of the Cartagena Agreement entitles the General Secretariat to determine the existence of restrictions on trade but does not empower it to restrict the capacity of Member States to rule or perform any activity in their own territories. The introduction of the concept of MEQRs with its Dassonville definition cannot be used to go beyond the text of the Cartagena Agreement for the sake of free trade. The reference to the Dassonville formula in this case was out of context. Any national infringement of community law will be dealt with under the proper procedures established in the Andean legal order. Consequently, as the ACJ has consistently held, the Resolution of the General Secretariat in this kind of procedure must be limited to a declaration that a national measure constitutes a restriction on trade in light of the text of the Cartagena Agreement. ${ }^{82}$ The ACJ has clarified that since the legality of such a Resolution is subject to judicial review, it is the ACJ which has the task of defining whether a unilateral measure adopted by a Member State amounts to a levy or restriction. ${ }^{83}$ However, the Resolutions of the General Secretariat impose on the Member States an obligation to immediately fulfill the Resolution in question, regardless of the possibility to challenge it through an action of annulment. $^{84}$

\subsection{Article 34 TFEU as the source of inspiration of the Cartagena Agreement}

Is it possible to consider alternative approaches to the application of EU standards in the determination of restrictions on imports? In the determination of restrictions on imports, the General Secretariat has been guided by the international practice. ${ }^{85}$ However, this approach has been contested by Member States, such as Colombia. In the Sudamtex nullification action, Colombia challenged the General Secretariat's authority to apply the European jurisprudence and doctrine in the determination of restrictions on trade. From the Colombian perspective, the international practice cannot extend the scope of Article 74 of the Cartagena Agreement. The arguments raised by Colombia clearly reflect the fear states have of broadening the authority of community institutions to intervene in their national regulatory autonomy by accepting broad interpretations.

The General Secretariat held in its Resolution 047 that Article 34 TFEU was the source of inspiration of Article 74 of the Cartagena Agreement, cited the former European Commission Directive 70/50/CEE of 1969 that defined MEQRs, and quoted the European doctrine in its reasoning in order to determine the existence of restrictions on trade. ${ }^{86}$ It seems that this European inspiration to the provisions of the Cartagena Agreement has been one of the grounds for justification of the General Secretariat's choice to apply the Dassonville formula. Colombia complained to the Court, arguing that Article 3 of the 1960 Treaty of Montevideo ${ }^{87}$ was the

\footnotetext{
${ }^{82}$ ACJ Ruling 125-AI-2004.

${ }^{83}$ ACJ Ruling 121-AI-2003.

${ }^{84}$ ACJ Ruling 72-AI-2000.

${ }^{85}$ General Secretariat Resolution 019.

${ }^{86}$ General Secretariat Resolution 047.

87 The 1960 Treaty of Montevideo created the Latin American Free Trade Association (LAFTA), which was replaced by the Latin American Integration Association (ALADI) established by the 1980 Treaty of Montevideo.
} 
source of inspiration of Article 72 and 73 of the Cartagena Agreement rather than the TFEU. Based on this proposition, Colombia argued that there was an erroneous motivation for Resolution 047. In its ruling 2-AN-98, the ACJ declined to accept or deny this fact and limited itself to pointing out that Colombia had not proved that the TFEU was not one of the sources of inspiration of Articles 72, 73 and 74 of the Cartagena Agreement. In any case, the ACJ took the view that a possible error of the General Secretariat as regards this matter did not affect the validity of its Resolution. Consequently, the ACJ upheld the General Secretariat's decision which considered the measure adopted by Colombia as a restriction on trade. ${ }^{88}$ Some questions arise in the context of the statement of the ACJ concerning the burden of proof. How could Article 34 TFEU inspire Article 74 of the Cartagena Agreement if the TFEU did not even establish an administrative stage in the determination of MEQRs?

Moreover, did Colombia really need to prove that the TFEU was not one of the sources of inspiration of Articles 72, 73 and 74 of the Cartagena Agreement in order to avoid the application of Dassonville? Would that have made any difference to the ACJ ruling or interpretation of the Cartagena Agreement provisions regarding the free movement of goods? If a possible error of the General Secretariat concerning this allegedly European inspiration does not render its Resolution invalid, as the ACJ held, it is not clear why the ACJ stressed the lack of proof on this issue. In any case, regardless of such a proof, the ACJ had long before introduced the concept of MEQRs, and in support of its decision on the Sudamtex case, the ACJ itself referred to the ECJ jurisprudence without any further explanation of its choice. Therefore, the ACJ has implicitly accepted this European inspiration of the Cartagena Agreement as regards the free movement of goods and, by doing so, it has justified its reliance on the ECJ case law. We contend that the inspiration from the TFEU does not necessarily imply the adoption of the same legislative techniques in the Cartagena Agreement, let alone the obligation to fully apply the ECJ jurisprudence on the free movement of goods without any caveats. Generally speaking, Article 34 TFEU and Article 72 of the Cartagena Agreement endorse the principle of free movement of goods and, in particular, aim at eliminating restrictions on imports between Member States. However, there are some differences regarding the manner in which the TFEU and the Cartagena Agreement regulate this principle. Article 72 of the Cartagena Agreement might be modeled on Article 34 TFEU in its general structures and purposes, but not in terms of its full content. It is apparent from the wording of these provisions that their interpretation may also have its own particularities in the context of Andean integration.

It is noteworthy that not all agreements that have introduced the concept of MEQRs have employed the ECJ case law concerning the free movement of goods. For example, Switzerland concluded a free trade agreement (FTA) with the EC (now the EU) in 1972. Article 13 thereof provides that "No new quantitative restriction on imports or measures having equivalent effect shall be introduced in trade between the Community and Switzerland." Some commentators have questioned whether it is legitimate to consider that Dassonville can be transposed to this provision and have pointed out that Swiss doctrine has shown, in this respect, extreme care taking into account the difference in objectives between the FTA and the current TFEU. ${ }^{89}$ On the other hand, it has been noted that "the Swiss Federal Tribunal has not accepted the Cassis de

\footnotetext{
${ }^{88}$ ACJ Ruling 2-AN-98.

${ }^{89}$ Jacot-Guillarmod, Olivier. Le juge national face au droit europeen: Perspective suisse et communautaire (Dossier de droit europeen, No.3) Bruxelles: Bruylan 1993.p.230.
} 
Dijon principle as relevant for its interpretation of either Art. 13 FTA (imports) nor of Art. 13A FTA (exports)." 90 Thus, the application of Dassonville may depend on the expected or established level of integration.

The ACJ stressed that a possible error of the General Secretariat in considering the TFEU as the source of inspiration of Articles 72, 73 and 74 of the Cartagena Agreement did not render its Resolution invalid. However, we should take into consideration that such argument was fundamental to the General Secretariat's choice of applying the wide Dassonville formula, and therefore to introduce potential acts as part of the definition of restrictions of all kinds when the Cartagena Agreement, as the ACJ has acknowledged, does not include a substantive provision for MEQRs. Therefore, some clarification on this aspect was necessary.

Significantly, the arguments raised by Colombia had some merits which were not further considered either by the General Secretariat or the ACJ. First, Article 3 of the 1960 Treaty of Montevideo ${ }^{91}$ called for the elimination of "restrictions of all kinds that affect the importation of products originating in the territory of any Member Country." Notably, this is the formula used by Article 72 of the Cartagena Agreement rather than the European model. However, the Treaty of Montevideo left the concept of "restrictions of all kinds" undefined. Another noteworthy aspect is that since its origins, the Andean Community desired a more advanced level of integration than that of the 1960 Treaty of Montevideo. ${ }^{92}$ In the same vein, Article 3 of the Cartagena Agreement envisages a more advanced schedule of trade liberalization than the commitments derived from the 1980 Treaty of Montevideo. Despite this desire, the formula used to enshrine the principle of free movement of goods was that of the Treaty of Montevideo and not the TFEU.

Second, it should also be noted that Article 3 of the 1960 Treaty of Montevideo defined the concept of levies, and Article 73 first paragraph of the Cartagena Agreement reproduces almost verbatim this definition. Even the exception contained in Treaty of Montevideo is reproduced in the Cartagena Agreement with the addition of only one word. Therefore, a comparison between Article 72 and Article 73 first paragraph of the Cartagena Agreement with Article 3 second and third paragraph of the 1960 Treaty of Montevideo reveals that Colombia had good reason to argue that the 1960 Treaty of Montevideo was the source of inspiration of Articles 72 and 73 of the Cartagena Agreement. This clarification turns out to be relevant since, as we will discuss below, the ACJ, in the absence of a treaty provision on the MEQRs, considered Article 34 TFEU as a supplementary source of law. ${ }^{93}$

Third, the provisions concerning the free movement of goods in the original Cartagena Agreement leave no doubt that the 1960 Treaty of Montevideo inspired the Cartagena Agreement in the definition of the principle of free movement of goods. Notably, Article 42 of

\footnotetext{
90 Tobler, Christa, Hardenbol, Jeroen and Mellár, Balázs. Internal Market beyond the EU: EEA and Switzerland. Briefing Paper. Directorate General for Internal Policies, European Parliament, 2010.p. 23. http://www.europarl.europa.eu/document/activities/cont/201003/20100315ATT70636/20100315ATT70636EN.pdf.

${ }^{91}$ All the Andean countries were Contracting Parties of the 1960 Treaty of Montevideo which was later amended by the 1980 Treaty of Montevideo.

${ }^{92}$ Article 3 c) of the 1969 Cartagena Agreement.

${ }^{93}$ ACJ Ruling 3-AI-96.
} 
the original Cartagena Agreement (what is now Article 73 thereof) did not list the exceptions to the free movement of goods as the present Article 73 does but rather it expressly pointed out that the grounds for the justifications provided for in Article 53 of the Treaty of Montevideo are not included in the concept of restrictions of all kinds. Article 53 thereof spelled out the exceptions to, among others, the obligation to eliminate restrictions of all kinds. This explicit reference made by Article 42 of the original Cartagena Agreement makes it clear that Colombia was right when it argued that the Treaty of Montevideo was the source of inspiration for what are now Articles 72 and 73 of the Cartagena Agreement. Thus, the argument of the General Secretariat that Article 74 of the Cartagena Agreement was inspired by Article 34 TFEU merits some observations. First, Article 34 TFEU does not empower the EU Commission to exclusively qualify whether a national measure adopted by an EU Member State is a restriction on trade. Second, the General Secretariat's statement seems to suggest that there are no other sources of inspiration for Articles 72-74 of the Cartagena Agreement, which is difficult to accept, especially when there are different legislative techniques that have been used in both foundational treaties.

Fourth, related to the last point, unlike the TFEU, the original Cartagena Agreement did not include the protection of industrial and commercial property as an exception to the free movement of goods. Therefore, a comparison of the 1960 Treaty of Montevideo with the Cartagena Agreement reveals that both treaties had the same exceptions to the free movement of goods and these exceptions have been retained despite the amendments that the Cartagena Agreement has undergone. Thus, on what grounds has the notion of MEQRs been introduced in Article 73 of the Cartagena Agreement? As regards the regulation of restrictions on imports, in particular in Articles 72 and 73 of the Cartagena Agreement, the drafters of the Cartagena Agreement clearly chose the formula of the Treaty of Montevideo for these provisions and not the TFEU.

3.5. Article 34 TFEU as a supplementary source of law for the interpretation of the free movement of goods in the Andean Community

The ACJ has clarified what the sources of community law in the Andean Community are. It has regarded primary law, secondary law and public international law as sources of Andean community law. The ACJ has also recognized unwritten sources of community law such as customary law and practice and general principles of law. Jurisprudence in application of community law has been seen as an instrument to guide the development of community law. ${ }^{94}$ The ACJ has also established that in the case of legal gaps in the Andean legal order, the general principles of community law, substantive law of the Member States and the principles of international law will be applied. It has added that, in a supplementary manner, use of the WTO provisions will be made subject to the compatibility of these multilateral norms with the principles and norms of the Andean Community. ${ }^{95}$ Throughout its case law, the ACJ has attempted to maintain judicial consistency in its propositions concerning the free movement of goods and has always referred to its earlier case law on the matter and has repeated the definition of restrictions on imports and the importance of the principle of free movement of goods in its rulings.

\footnotetext{
${ }^{94}$ ACJ Ruling 1-IP-96.

${ }^{95}$ ACJ Ruling 118-AI-2003.
} 
The ACJ has introduced the notion of MEQRs through its case law. Interestingly, the ACJ recognizes that the Cartagena Agreement does not include a substantive provision for MEQRs as Article 34 TFEU does. However, the ACJ takes the view that this provision of the TFEU, together with the provisions on quantitative restrictions of the GATT/WTO, can constitute $a$ valuable supplementary source of law. ${ }^{96}$ This assertion of the ACJ seems to justify its choice to follow the ECJ case law. Taking into account that all the Member States of the Andean Community are Members of the WTO and the fact that the ACJ has recognized that international treaties signed by the Andean states are sources of community law, ${ }^{97}$ the reference to the GATT is understandable. ${ }^{98}$ Notably, neither the General Secretariat nor the ACJ has referred to particular decisions of the WTO dispute settlement organs when deciding a case concerning Articles 72 and 73 of the Cartagena Agreement. Both institutions have relied on the ECJ jurisprudence as regards the free movement of goods.

The ACJ ruled that the application of a prior authorization to imports was a restriction on trade, citing the ECJ ruling 29/87 in which the ECJ held that prior authorizations applied to imports constituted MEQRs. ${ }^{99}$ By introducing the definition of MEQRs developed by the ECJ, the ACJ's approach limits the state's discretion to impose restrictions on imports and gave the Andean Community the competence and authority to deal with a much broader range of barriers to trade. This ACJ option may be explained by what has been the guiding principle of the ACJ: the defense of the free movement of goods. ${ }^{100}$

In the context of the Andean Community, Article 73 second paragraph of the Cartagena Agreement reflects the consensus among the Member States on what is to be understood by "restrictions of all kinds" and the ACJ has not explained on which grounds it has regarded Article 34 TFEU as a supplementary source of law in the Andean Community to introduce the concept of MEQRs. It is not yet clear what implications this ACJ position may have regarding the obligations of the Andean Member States. Should the ACJ pay close attention to identifying the legal or other basis for referring to certain instruments, such as the TFEU, as sources of Andean Community law in support of its rulings? It seems that the ACJ has taken the TFEU as a reference point to bridge the gap left by the drafters of the Cartagena Agreement when they omitted the notion of measures of equivalent effect.

Nevertheless, despite this ACJ jurisprudence, surprisingly, in its Ruling 2-AI-96, the ACJ changed its approach towards the ECJ case law. Article 36 TFEU provides for the protection of industrial and commercial property as a ground for justifying the introduction of restrictions on imports. By contrast, in the Andean Community, the protection of industrial and commercial property as an exception to the free movement of goods is not provided for in the Cartagena Agreement but rather in secondary legislation. ${ }^{101}$ After acknowledging this difference concerning the legal source of this exception to the free movement of goods, the ACJ concluded

\footnotetext{
${ }^{96}$ ACJ Ruling 3-AI-96.

${ }^{97}$ ACJ Ruling 2-AI-96.

${ }_{98}$ ACJ Ruling 2-AI-96.

99 ACJ Ruling 2-AI-97.

100 ACJ Ruling 2-AI-97.

${ }^{101}$ Articles 159 Decision 486 Common Intellectual Property Regime.
} 
that the European jurisprudence and doctrine cannot be fully applicable to the Andean case. ${ }^{102}$ The question that arises in this context is why Dassonville is applied in the Andean system if MEQRs were not even expressly included in the Andean foundational treaty when it defined restrictions of all kinds. Why has the ACJ used the ECJ standards on the concept of MEQRs? Consistent with the rationale of the ACJ argument in its Ruling 2-AI-96, it should have been declared in its case law that since MEQRs are not expressly included in Article 73 of the Cartagena Agreement, the Dassonville formula could not be fully applicable to the Andean case. In Ruling 2-AI-96, the ACJ resorted to the Agreement on Trade-Related Aspects of Intellectual Property Rights (TRIPS) after indicating that international treaties signed by Member States are sources of community law. Nonetheless, the ACJ made a preliminary observation: the utilization of these multilateral rules is conditioned upon their compatibility with Andean rules. ${ }^{103}$ In sharp contrast, in its Ruling 3-AI-96, the ACJ did not explain the reasons to affirm that the TFEU can constitute a valuable supplementary source of law and it did not introduce any condition for its utilization.

It is submitted that in many instances the utilization of the ECJ's concept of MEQRs by the ACJ was unnecessary. For example, in the above-mentioned case concerning prior import authorizations, these kinds of administrative measures are among the most visible and classic restrictions on trade. The ACJ did not need to quote the ECJ ruling 29/87 to back up its interpretation of Articles 72 and 73 of the Cartagena Agreement, introducing the concept of MEQRs. Article 73 of the Cartagena Agreement prohibits administrative measures that obstruct or hinder imports and this entails import authorizations. Instead, although it has not been expressly said by the ACJ, the ACJ's choice reflects its understanding that Article 34 TFEU is broader than Article 73 second paragraph of the Cartagena Agreement and this may explain the reference that this institution, along with the General Secretariat, has made to the European treaty.

It is not clear that the Cartagena Agreement allows for such a broad interpretation without any caveats in the light of the Andean integration process. The ECJ definition of MEQRs reflects certain political and economic choices. The development of the ECJ case law regarding Article 34 TFEU is the consequence of the development of the European state of integration. ${ }^{104}$ This formula, as Chalmers puts it, "reflects a philosophy of extreme economic liberalism”. ${ }^{105}$ Further thought concerning whether this is what the Cartagena Agreement seeks to protect is needed.

The drafters of the Cartagena Agreement wanted to include all charges of equivalent effect when they worded the provision concerning levies. However, when they worded the provision concerning non-tariff barriers, they chose a different legislative technique. First, they omitted the expression MEQRs. Second, they departed from the EU model which left the notions of Article 34 TFEU undefined.

\footnotetext{
102 ACJ Ruling 2-AI-96.

103 ACJ Ruling 2-AI-96.

${ }^{104}$ Wils, Wouter P.J. The search for the rule in Article 30 EEC: much ado about nothing? (1993) E.L.Rev. p. 485.

${ }^{105}$ Chalmers, Damian. Free movement of goods within the European Community: an unhealthy addiction to scotch whisky? (1993) 42 E.L.Rev. p. 275.
} 


\section{Why do the Andean institutions use the ECJ case law on the free movement of goods?}

\section{1. $\quad$ The meaning of a common market}

In Commision v. Italy, the ECJ referred to customs or frontier controls in cross-border trade, and asserted that "These residuary controls must nevertheless be reduced as far as possible so that trade between Member States can take place in conditions as close as possible to those prevalent on a domestic market”. ${ }^{106}$ The ACJ employed this approach in its Ruling. Indeed, it has followed a simple approach and invoked this judgment by the ECJ to assert that this is in fact what the elimination of levies and restrictions of all kinds seeks to achieve in the Cartagena Agreement. Notably, the free movement of goods is perceived as an instrument for establishing an Andean market without internal frontiers. Building on the idea expressed by the ECJ in Commision $v$. Italy, the ACJ stressed that the absolute liberalization of intra-Community trade must be perceived as far as possible as a situation similar to that existing in the territory of the Member States, by achieving a merger of the national markets in a common economic space, without internal frontiers that present difficulties of any kind. ${ }^{107}$ This ACJ rationale resembles that in Gaston Schul where the ECJ asserted that: "The concept of a common market...involves the elimination of all obstacles to intra-Community trade in order to merge the national markets into a single market bringing about conditions as close as possible to those of a genuine internal market”. ${ }^{108}$ The ACJ has stressed that this kind of cooperation, which allows the internal development of trade in conditions similar to those of a domestic market, is the only manner in which the Andean integration process will survive in the face of other integration blocs on a continental and global scale. ${ }^{109}$

The ACJ has assumed that since these two regional organizations have the same purpose, the same understanding of a common market should be adopted. Accordingly, the ECJ case law regarding the interpretation of Article 34 TFEU has been used by the ACJ in order to clarify the objective of the principle of free movement of goods in the Andean Community. The ECJ definition of a common market has provided the basis for the ACJ to rule on national measures that may obstruct or hinder imports. The ACJ ruling reflects the interest in the elimination of all barriers to trade.

4.2. The objective of Article 34 of the Treaty on the Functioning of the European Union and Articles 72 and 73 of the Cartagena Agreement

The principle of free movement of goods is rooted in the notion of preventing unilateral trade barriers. The TFEU recognizes this principle of free movement of goods. In light of Article 34 TFEU “Quantitative restrictions on imports and all measures having equivalent effect shall be prohibited between Member States.” In addition, Article 24 paragraph 2 of the aforementioned agreement states that "The internal market shall comprise an area without internal frontiers in

\footnotetext{
${ }^{106}$ Case 159/78 Commission v Italian Republic [1979] E.C.R. 03247.

107 ACJ Ruling 2-AN-98. See also Ruling14-IP-2008.

${ }^{108}$ Case 15/81, Gaston Schul Douane Expediteur BV v Inspecteur der Invoerrechten en Accijnzen, Roosendaal, [1982] ECR 1409 at 1431-1432.

109 ACJ Ruling 3-AI-96, Ruling 2-AI-96.
} 
which the free movement of goods, persons, services and capital is ensured in accordance with the provisions of the Treaties." In Commission v. France, ${ }^{110}$ the ECJ expressed the view that that the intention of Article 34 TFEU was the elimination of all barriers to trade and this has been understood as "an indispensable instrument for the realisation of a market without internal frontiers.”

The ACJ has pointed out that the principle of free movement of goods is a means to protect the juridical interest of the Andean Community so as to allow the trade between Member States to be free of tariff and non-tariff barriers. The ACJ has also stressed not only the importance but also the function of this principle as an instrument for the interpretation and application of community law. ${ }^{111}$ In addition, the ACJ has regarded the free movement of goods as a basic principle in the process of integration of the states. ${ }^{112}$

Generally speaking, it seems that the main objective of Article 34 TFEU and Articles 72 and 73 of the Cartagena Agreement is the elimination of non-tariff barriers to trade based on the view that these measures constitute an obstacle to achieving the common market. The ECJ and ACJ case law has unreservedly affirmed that the free movement of goods is one of the most important and fundamental principles in their integration process. Both the $\mathrm{ECJ}^{113}$ and the ACJ ${ }^{114}$ have recognized that the free movement of goods is one of the fundamental principles of the TFEU and the Cartagena Agreement, respectively. This principle has been seen by these courts as one of the fundamental mechanisms to achieve the common market. ${ }^{115}$

\subsection{The similarities between the European and Andean institutional systems}

The ACJ has emphasized the similarities between the European and Andean systems. The judge of the ACJ, Ricardo Vigil Toledo, has said that the Andean Community adopted the European model, which explains why the structure and attributes of the ACJ are so similar to those of the ECJ. In his view, this is also the reason why the ACJ closely followed the development of the ECJ jurisprudence and the reason for the existence of the close cooperation between the two tribunals. He also affirmed that the nature and characteristics of the Andean community law are similar to the EU law. ${ }^{116}$

Thus, the jurisprudence of the ECJ has become an important source of inspiration, interpretation and orientation for the ACJ and the General Secretariat. Nevertheless, the inspiration from the European model does not amount to a careless importation of principles and legal techniques, but rather the ACJ has its own features that differ from those of the ECJ. The ACJ has adopted a

\footnotetext{
${ }^{110}$ Case C-265/95. Commission v French Republic [1997] E.C.R. I-06959.

111 ACJ Ruling 2-AI-96.

112 ACJ Ruling 04-IP-98.

113 Case C-265/95. Commission v French Republic [1997] E.C.R. I-06959; Case 120/78 Rewe-Zentral AG v Bundesmonopolverwaltung für Branntwein [1979] E.C.R. 00649.

114 ACJ Ruling 3-AI-96.

${ }^{115}$ Case 28/84 Commission v Federal Republic of Germany [1985] E.C.R. 03097; Case C-265/95 Commission v French Republic [1997]ECR I-06959. See also ACJ Ruling 1-IP-90; ACJ Ruling 2-AN-98.

${ }^{116}$ Vigil Toledo, Ricardo. El reflejo de la jurisprudencia europea en los fallos del Tribunal de Justicia de la Comunidad Andina: aspectos teóricos y pragmáticos. Barcelona, Universitat Pompeu Fabra, February 10, $2011 . p .1$. http://www.upf.edu/constitucional/actualitat/PDFs/abstracts/Vigil.pdf. (10.04.2011).
} 
balanced approach in applying the ECJ doctrines in other areas of law by adapting these doctrines to the Andean context. For instance, in the case of preliminary rulings, the ACJ has so far refused to apply the doctrine of acte eclaire in an attempt to promote the submission of preliminary rulings by national courts. ${ }^{117}$ In this respect, the ACJ's decisions reflect some adaptation to the Andean reality.

\subsection{The wide scope of the Dassonville formula and the need to establish an Andean common market}

As regards the interpretation of Article 34 TFEU, Chalmers et al. argue that "the breadth of the definition can then be understood as an establishment of jurisdiction. By making Article 34 [TFEU] broad, the Court is granting itself equally broad powers to supervise national measures compatible with the Treaty. This was particularly important in a time where the internal market was in its infancy and national protectionist traditions were well-entrenched, while national judges were still often unfamiliar with EU law"118 The reason why the ECJ jurisprudence has been taken up by the General Secretariat and the ACJ is because of its wider scope. The Dassonville formula has given the ACJ and the General Secretariat a comprehensive tool that they can apply in concrete cases where national states' measures allegedly hinder the free movement of goods. This is reflected in the jurisprudence of these Andean institutions.

The Dassonville formula had been applied in the Andean Community to facilitate arguments of policy. When dealing with national restrictions on trade both the General Secretariat and the ACJ have repeatedly emphasized that the desire to create a common market expressed by the Member States is undermined by the imposition of restrictions. The General Secretariat has underlined that the elimination of restrictions on trade between Member States is a fundamental element in the process of establishing the common market. ${ }^{119}$

Does every common market need Dassonville? The Dassonville formula was regarded as a means to support the establishment of the Andean common market. The ABBA case illustrates the General Secretariat's approach. In its Resolution 449, the General Secretariat reaffirmed the Dassonville formula and explained the reason for its use by unequivocally stating that with the aim of ensuring the due functioning of the common market there is a need to decide on cases that directly or indirectly, actually or potentially can restrict imports through acts that may have a limiting effect on trade. ${ }^{120}$ The case law of the ACJ has not amended this understanding. With this European formula, the General Secretariat opened the door to include a wide range of national restrictive measures that can be assessed in the light of the Cartagena Agreement and implicitly agreed that the concept of restrictions of all kinds must be widely interpreted. Thus from the General Secretariat's viewpoint, the term "restrictions of all kinds" has the same meaning as the term MEQRs has in Article 34 TFEU. Interestingly, in the EU, as Bernard notes

\footnotetext{
117 Alonso García, Ricardo. Un paseo por la jurisprudencia supranacional europea y su reflejo en los sistemas suramericanos de integración.p.408. Revista de la Facultad de Derecho 2005-2006, No. 60-61, Universidad Católica Andrés Bello, Caracas, 2009.

${ }^{118}$ Chalmers, Damian, Davies, Gareth and Monti, Giorgio. European Union Law: Cases and materials. Cambridge: Cambridge University Press, 2010. p. 8-9.

${ }^{119}$ General Secretariat Resolutions 724, 638, 634, 604, 490, 371, 357, 258, 244, 209.

${ }^{120}$ General Secretariat Resolution 449.
} 
"Dassonville proceeds by way of a peremptory definition without any explanation as why the context of the internal market necessitates such a definition. It is as if the notion of a measure having equivalent effect was so self-evident as not to require any explanation.”121

If the General Secretariat and the ACJ refer in their reasoning to the application of the Dassonville doctrine in particular, and to the ECJ case law as regards the free movement of goods in general, this implies, in turn, that they are bound to take into account the problems and confusion that this formula may bring about.

In Europe, the question of whether these doctrines (Dassonville and Cassis de Dijon) could be applied without restrictions arose and national courts have sought the clarification from the ECJ. Kapteyn observes that "In a number of cases, the question arose whether the Dassonville/Cassis de Dijon approach could apply unrestrictedly. In the 1980s, the Court handed down a number of judgments in which measures such as a prohibition on night transport for bread, or a prohibition of the sale of certain drinks in cafés, were found not to come within the scope of Article 28 EC. As a result of these judgments, the discussion on the scope of the concept of measures having equivalent effect in relation to imports flared up again." 122 In any event, the scope and breadth of Article 34 TFEU is not settled. Weatherill notes that "there are persisting questions about, first, the type of practice that is subject to control in the name of protecting the free movement of goods...". ${ }^{123}$ Over the years, there has been academic discussion about the limits of this provision in European integration ${ }^{124}$ and the new challenges that the ECJ case law faces in the current economic crises. ${ }^{125}$ The ECJ itself reviewed its broad interpretation of Article 34 TFEU given in its Dassonville ruling. Indeed, the ECJ set some limits to this formula in the well-known Keck and Mithouard judgment, where the ECJ decided that non-discriminatory selling arrangements are not MEQRs and therefore they are outside the scope of Article 34 TFEU. By doing so, the ECJ, as Baudenbacher put it, "shifted sovereignty back to the Member States" reflecting a "more conservative attitude". ${ }^{126}$ The ACJ has not had the occasion to exclude certain measures as the ECJ did with the Keck and Mithouard case. As yet, there is no judgment similar to Keck and Mithouard in the Andean Community. Although the General Secretariat has quoted this ruling to emphasize that Article 34 TFEU does not limit the scope of the term "measure", 127 it has not shed further light on how the Keck approach should be applied in the Andean Community. It has not observed that the Keck ruling represented a delimitation of the term MEQRs. One question remains as to how the ACJ will react when facing a case concerning selling arrangements. Will the ACJ include or exclude selling arrangements from the scope of Articles 72 and 73 of the Cartagena Agreement?

\footnotetext{
${ }^{121}$ Bernard, Nicolas. On the Art of Not Mixing One’s Drinks: Dassonville and Cassis de Dijon Revisited. In: Maduro, Miguel Poiares and Azoulai, Loïc (Eds). The Past and Future of EU Law: The Classics of EU Law Revisited on the 50th Anniversary of the Rome Treaty. Oxford and Portland, Oregon: Hart Publishing, 2010. p.459.

122 Kapteyn. Op.cit. p.626.

${ }^{123}$ Weatherill, Stephen. Free movement of goods. ICLQ vol 61, April 2012 p.541.

${ }^{124}$ White, Eric L. In search of the limits to Article 30 of the EECTreaty. (1989) C.M.L. Rev.235-280.

${ }^{125}$ Hojnik, Janja. Free movement of goods in a labyrinth: Can Buy Irish survive the crises? (2012) 49 Common Market Law Review, Issue 1, pp. 291-326.

${ }^{126}$ Baudenbacher, Carl. Judicialization: Can the European Model Be Exported to Other Parts of the World? Texas International Law Journal 2004, Vol. 39. p.385.

${ }^{127}$ General Secretariat Resolution 47.
} 
Moreover, in the EU, as Weatherill observes "The problem is pinning down with precision where Article 34 TFEU stops and where national regulatory autonomy begins.” Justifying the application of the Dassonville formula for the benefit of the common market in the Andean Community is not a convincing argument since it implies a limitation to state regulatory autonomy. The Dassonville formula as utilized by the General Secretariat and endorsed by the ACJ must also be seen in light of the definitional delimitation challenge that it poses. And, the ACJ and the General Secretariat are bound to consider their own founding legislation in addressing measures that affect cross-border trade.

\subsection{The promotion of the Andean integration as a policy objective}

By adopting the Dassonville formula as a definition of the free movement of goods in the Andean Community, the ACJ and the General Secretariat sought to expand the scope of the principle of free movement of goods. The analysis of the case law of the ACJ and the Resolutions of the General Secretariat in the area of free movement of goods suggests that both the ACJ and the General Secretariat have taken on the role of promoting the Andean integration as regards the free movement of goods and have limited, as far as possible, government discretion in this area.

First, the ACJ has expressly declared the need to maintain and defend the principle of free movement of goods to strengthen the integration process. ${ }^{128}$ The ACJ built upon the ideas revealed in the judgments it delivered in the 1990s concerning the importance of the free movement of goods, ${ }^{129}$ and has stressed the importance of the elimination of obstacles to trade for the economic integration and the key role that the principle of free movement of goods plays in the achievement of the common market. ${ }^{130}$ Throughout its rulings since the 1990s, wherever the ACJ has had the occasion to address the Tariff Reduction Program, it has recalled the importance of this program in attaining the objectives of the Andean integration process. ${ }^{131}$ The ACJ has also built on the political support expressed by the Member States in their guidelines to eliminate restrictions of all kinds. ${ }^{132}$ The ACJ ensures that this principle is one of the pillars of the integration process, and connected to the general interest of the Andean Community. ${ }^{133}$ This essential freedom was envisaged as one of the main tools to achieve the Andean and Latin American integration. ${ }^{134}$

Second, the ACJ has been confronted with the question of conflict between WTO and Andean law. In this context, the ACJ has not accepted the argument that restrictions on imports can be unilaterally imposed by states if those measures are consistent with other international obligations. The ACJ did not agree with Colombia that because its national measures were consistent with the Agreement on Import Licensing Procedures of the WTO, the measures did not violate Andean rules. The ACJ declared non compliance by Colombia and asserted the

\footnotetext{
${ }^{128}$ ACJ Ruling 2-AI-97.

${ }^{129}$ ACJ Ruling 1-IP-90, Ruling 5-IP-90, Ruling 3-IP-93, Ruling 3-AI-96.

${ }^{130}$ ACJ Ruling 3-AI-96.

${ }^{131}$ ACJ Ruling 3-AI-96, Ruling 5-IP-90, Ruling 3-IP-93. In its Ruling 14-IP-2008, the ACJ stressed the importance of fulfilling the Tariff Reduction Program to advance the integration process.

132 ACJ Ruling 3-IP-93, Ruling 3-AI-96.

133 ACJ Ruling 2-AN-98, Ruling 1-AI-97.

${ }^{134}$ ACJ Ruling 1-AI-97.
} 
principle of primacy of the Andean legal order over other international obligations, including those under the WTO. ${ }^{135}$ In its Ruling 28-AI-2001, the ACJ also rejected the argument of Ecuador which tried to justify its restrictive measures based on the Agreement on the Application of Sanitary and Phytosanitary Measures of the WTO. Thus, any commitment made by the states in their external relations should not affect the principle of free movement of goods.

Third, consumer protection was not included in the list of exceptions provided for by Article 73 of the Cartagena Agreement. Nevertheless, Decision 376, amended by Decision 419 of the Andean Community Commission allows Member States to adopt technical regulations aimed at promoting the quality of products and services which are exchanged in international trade, and for the protection of health, safety, the environment and the consumers. The ACJ has relied on the existence of this secondary law concerning the competence of states to implement technical regulations to emphasize that consumer protection measures have a limit, namely that their application cannot represent an obstacle to trade. In a non-compliance judgment, the ACJ declared the non-compliance of Venezuela because it had imposed labeling requirements on shoes, which could not be justified in light of the need to protect consumer rights. ${ }^{136}$ This strict approach reflects the strong standing of the principle of free movement of goods.

Fourth, Alter reviewed the preliminary rulings and non-compliance judgments of the ACJ and argued that "The [ACJ] has also eschewed opportunities to expand the reach and scope of Andean law. While the [ACJ] formally treats the Cartagena Agreement as higher-order law, the tribunal readily defers to collective decisions concerning the scope and pace of Andean integration when interpreting the treaty. This approach gives member states broad discretion to revise Andean rules to reflect the waxing and waning of their collective commitment to integration." ${ }^{137}$ While this conception may hold true in other areas of Andean law, as regards the principle of free movement of goods it is clear that the ACJ has seized the opportunities it had to adopt a broad interpretation of this principle and it has clearly expanded its scope and nature by introducing the concept of MEQRs and accepting the Dassonville formula.

Fifth, the ACJ's judgments favor trade liberalization, but they have also attempted to strike a balance between competing principles, namely the principle of free movement of goods and other principles or rights protected by the Andean legal system such as intellectual property rights (IPRs). The ACJ in its rulings has not overlooked the interests of states regarding the protection of IPRs. In its Ruling 2-AI-96 the ACJ encouraged the conciliation between the protection of the legitimate exercise of IPRs and the need to prevent the abusive exercise of such rights, which can artificially limit trade in the Andean region. ${ }^{138}$ The underlying rationality has also been to ensure that the protection of IPRs does not undermine the essential principle of free movement of goods.

\footnotetext{
135 ACJ Ruling 118-AI-2003. See also ACJ Ruling 117-AI-2003.

${ }^{136}$ ACJ Ruling 125-AI-2004.

${ }^{137}$ Alter, Karen J. and Helfer, Laurence R. Nature or Nurture? Judicial Lawmaking in the European Court of Justice and the Andean Tribunal of Justice. International Organization 64, Fall 2010.p. 579.

138 ACJ Ruling 2-AI-96.
} 


\section{6. $\quad$ The need to apply the principle of proportionality}

The ACJ has guided national authorities in exercising their discretion concerning the application of restrictions on trade. The General Secretariat ${ }^{139}$ and the ACJ ${ }^{140}$ have developed the concept of proportionality in order to assess the application of exceptions to the general rule of elimination of restrictions on trade. The case law of the ACJ and the Resolutions of the General Secretariat reveal that these exceptions are strictly interpreted. Attention is paid to avoiding the misuse of the discretion granted to Member States. Notably, unlike the TFEU and the GATT, the Cartagena Agreement does not expressly set out any requirements for the application of these exceptions. This Agreement makes no reference to the need to avoid the utilization of these exceptions as an arbitrary, unjustified or disguised restriction on trade. Nevertheless, this omission has not prevented the ACJ from applying tests to assess the reasonable nature of the restrictive measures adopted by Member States based on the exceptions laid down in Article 73 of the Cartagena Agreement.

The proportionality principle has been adopted by the General Secretariat and the ACJ in its case law. According to the ACJ, there must be proportionality between the restrictive measure and the specific object to which it is addressed. A measure adopted outside the scope of its specific object, which makes imports impossible cannot be justified, especially if the measure is of a discriminatory nature. The ACJ expressed the view that the same holds true if the object pursued by the national measure can be attained by other means which do not amount to a hindrance to trade. The application of this proportionality principle ensures that the national restrictive measure does not threaten the essential purpose of the integration, namely the free movement of goods. $^{141}$

It is settled ACJ case law that three requirements must be fulfilled by a national measure for it to be considered an exception covered by Article 73 of the Cartagena Agreement. First, there must be proportionality between the restrictive measure and the specific object pursued. Second, there must be a direct and immediate relation between such a measure and the solution of the specific problem addressed. Third, the objective pursued by such a measure cannot be attained by other means which are less of a hindrance to trade. ${ }^{142}$

The ACJ introduces a necessity test when reviewing the exceptions spelled out in Article 73 of the Cartagena Agreement. According to the ACJ, the legitimacy of any control, procedure or formality that a Member State might require can only be assessed in light of community law. Formalities requirements can only be justified if they are necessary to establish whether the measure at hand is covered by one of the non-economic exceptions laid down in Article 73 of the Cartagena Agreement. ${ }^{143}$ Furthermore, the ACJ judgments have influenced the work of the General Secretariat which has followed and built on the decisions of the ACJ to support its analysis in all the administrative procedures to determine the existence of restrictions on imports. These three criteria have been reiterated by this institution in every Resolution where the

\footnotetext{
${ }^{139}$ General Secretariat Resolution 1289.

140 ACJ Ruling 3-AI-96, 1-AN-97 and 5-AN-97.

141 ACJ Ruling 3-AI-96.

142 ACJ Ruling 5-AN-97. See also ACJ Ruling 1-AN-97, Ruling, 3-AI-97, Ruling 3-AI-96, Ruling 118-AI-2003.

143 ACJ Ruling 2-AN-98.
} 
necessity and proportionality of a restrictive measure was addressed. ${ }^{144}$ A number of cases have dealt with the question of proportionality. Under this framework, a prohibition on the entry of bananas because of a risk of transmitting illness, imposed by Peru against Ecuador, was considered as an obstacle to intra-community trade on the basis that the prohibition exceeded what is needed for sanitary protection. ${ }^{145}$ In the same vein, a ban on the importation of explosives and the like, which compete with national production, was considered not reasonable to protect the national security of a Member State. The General Secretariat clarifies that the exceptions laid down in Article 73 of the Cartagena Agreement do not apply for protectionist purposes. ${ }^{146}$ A prohibition on the importation of roasted coffee from Colombia and the decision not to grant phytosanitary permits to protect against Coffee Berry Borer imposed by Venezuela were regarded as restrictions on trade. The former Junta (the predecessor of the current General Secretariat) found that it is viable to establish inspections earlier in the process, i.e. during the pre-shipment process in order to verify the sanitary conditions indicated in the phytosanitary certificate instead of prohibiting imports. ${ }^{147}$ Therefore, guided by the principle of free movement of goods, only the inevitable restrictions to trade can be justified on the grounds of general interest.

These requirements applied by the Andean institutions concerning derogation to the free movement of goods resemble Article 3 of the former European Commission Directive 70/50 of 1969 which formulated the idea of proportionality and the need to consider whether "the same objective can be attained by other means which are less of a hindrance to trade."

In the EU, under the Cassis de Dijon formula, undue and unnecessary burdens on intracommunity trade are not allowed. In the light of the approach developed by the ECJ, in order to justify derogation from the principle of the free movement of goods, the non-discriminatory restrictive national measure must be necessary. The objective pursued must be identified so as to assess the necessity of its application. The ECJ has formulated the proportionality principle such that the application of national measures that restrict inter-State trade can only be justified if they are "proportionate to the aim in view. If a Member State has a choice between various measures to attain the same objective it should choose the means which least restricts the free movement of goods." 148

It can be seen that the ACJ jurisprudence regarding the proportionality principle very closely resembled that of the ECJ.

\footnotetext{
144 General Secretariat Resolution 986, Resolution 966, Resolution 897, Resolution 759, Resolution 748, Resolution 715, Resolution 576, Resolution 440, Resolution 308, Resolution 184.

145 General Secretariat Resolution 432.

${ }^{146}$ General Secretariat Resolution 201. See also Resolution 407.

147 General Secretariat Resolution 397.

${ }^{148}$ Case 261/81 Walter Rau Lebensmittelwerke v De Smedt PVBA [1982] E.C.R. 03972. See also Case $448 / 98$ Criminal proceedings against Jean-Pierre Guimont [2000] E.C.R. I-10663. Case 39/90 Denkavit Futtermittel GmbH v Land Baden-Württemberg [1991] E.C.R. I-03069; Case 368/95 Vereinigte Familiapress Zeitungsverlags- und vertriebs GmbH v Heinrich Bauer Verlag [1997] E.C.R.I-03689 .
} 


\section{Conclusion}

The Resolutions of the General Secretariat reviewed, and the case law of the ACJ regarding restrictions on imports, suggest that these institutions have tried to ensure the fulfillment of state obligations in favor of the principle of free movement of goods as an essential and important avenue to attain the common market in the Andean Community. Since the early 1990s, through the jurisprudence on the free movement of goods, the ACJ has adopted a broad interpretation of the provisions of the Cartagena Agreement. The need to interpret the Cartagena Agreement based on the need to establish a common market triggers the application of a broad definition of restriction on trade, such as the ECJ Dassonville doctrine. The Dassonville formula helped not only to understand the meaning of "restrictions of all kinds" provided for in Article 73 of the Cartagena Agreement but also to delimit the competence of community institutions as regards the assessment of restrictive national measures.

The TFEU and the ECJ case law are a source of inspiration for the General Secretariat and the ACJ when determining the existence of a restriction on trade. Both community institutions cite the ECJ case law, Article 34 TFEU, and the European doctrine. Some aspects of the ACJ case law need to be further clarified. In light of the ACJ case law, Article 34 TFEU has acquired the status of supplementary source of law in the Andean Community. Nevertheless, the ACJ needs to develop or explain the implications of this position adopted in the 1990s. As yet, the ACJ has not done this work. A special challenge for the ACJ follows from the fact that the Cartagena Agreement has adopted a different approach to restrictions on trade to that found in the text of the TFEU and it does not contain a clause for MEQRs. Additionally, the Cartagena Agreement clearly takes a position concerning the concept of restrictions of all kinds. 